\title{
MENGOPTIMALKAN FAKTOR DIRI DAN KELUARGA DALAM PRESTASI AKADEMIK REMAJA
}

\author{
Nuraini Novianti, Melly Latifah'), Neti Hernawati \\ Departemen IImu Keluarga dan Konsumen, Fakultas Ekologi Manusia, Institut Pertanian Bogor, \\ Bogor 16680, Indonesia \\ *Email : mellylatifah@yahoo.com
}

\begin{abstract}
Abstrak
Prestasi akademik remaja dapat dipengaruhi berbagai faktor internal maupun eksternal. Faktor internal dalam penelitian ini adalah faktor yang berasal dari diri remaja yaitu motivasi dan strategi pengaturan diri dalam belajar. Sementara itu, faktor eksternal remaja yang dimaksud adalah faktor dari keluarga dalam bentuk gaya pengasuhan yang diterapkan orang tua. Penelitian ini bertujuan untuk menganalisis pengaruh gaya pengasuhan, motivasi, dan strategi pengaturan diri dalam belajar terhadap prestasi akademik remaja. Pengambilan data dilakukan dengan teknik pelaporan diri menggunakan alat bantu kuesioner yang melibatkan 149 siswa kelas VIII dari dua Sekolah Menengah Pertama Negeri di Bogor. Hasil penelitian menemukan bahwa sekitar sembilan dari sepuluh remaja memersepsikan ibunya menerapkan gaya pengasuhan otoritatif $(89,3 \%)$. Hasil penelitin juga menemukan bahwa lebih dari separuh remaja memiliki motivasi kategori sedang $(53,0 \%)$ dengan motivasi yang lebih banyak digunakan adalah dimensi effort/importance. Tujuh dari sepuluh remaja memiliki strategi pengaturan diri dalam belajar remaja pada kategori rendah (72,3\%) dan dimensi yang sudah cukup baik dilakukan adalah effort regulation. Prestasi akademik remaja hampir seluruhnya $(95,3 \%)$ terkategori baik. Model regresi linier berganda menunjukkan bahwa lama pendidikan ibu dan gaya pengasuhan otoriter berpengaruh negatif signifikan terhadap prestasi akademik. Sementara itu, gaya pengasuhan otoritatif ibu dan strategi pengaturan diri dalam belajar berpengaruh positif signifikan terhadap prestasi akademik.
\end{abstract}

Kata kunci: motivasi, otoritatif, otoriter, prestasi akademik, strategi pengaturan diri

\section{Optimizing Self and Families Factors on Adolescent's Academic Achievement}

\begin{abstract}
Abtract
Academic achievement is influenced by many factors such as internal factor and external factor. Internal factors in this research is a factor that can be used to learn. Meanwhile, the external factor of the adolescent involved is the factor of the family in the form of parenting style that implements the parents. This study aims to analyze the nurturing style, motivation, and strategies in learning against adolescent achievement. The data were collected using a questionnaire technique involving $149 \mathrm{VIII}$ students from two State Junior High Schools in Bogor. The results found that about nine of the adolescents perceived the authoritative parenting style $(89,3 \%)$. The results of the study also found that more than half of adolescents had moderate motivation categories $(53,0 \%)$ with broader motivation. Seven of the adolescents had a low learning strategy $(72,3 \%)$ and a fairly well-done dimension was the regulatory effort. The academic achievement of adolescents is almost entirely $(95,3 \%)$ is categorized well. Multiple linear regression models show that the duration of mother education and authoritarian parenting style have a significant negative effect on academic achievement. Meanwhile, the mother's authoritative parenting style and self-determination strategy in learning have a significant positive effect on academic achievement.
\end{abstract}

Keywords: authoritative, authoritarian, academic achievement, motivation, self regulation learning strategies

\section{PENDAHULUAN}

Masa remaja merupakan masa peralihan seseorang dari dunia anak-anak ke dunia dewasa dan biasanya terhitung dalam rentang usia 13 sampai 21 tahun (Gunarsa, 2010; Papalia et al., 2008). Menurut Gunarsa (2010) beberapa permasalahan remaja dapat terjadi terkait dengan beberapa aspek seperti intelegensi, penampilan fisik, keterampilan, status sosial, krisis identitas, maupun terkait dengan bakat khusus yang dimilikinya. Perubahan yang dialami remaja seringkali menimbulkan permasalahan bagi orang tua atau orang dewasa yang berhubungan dengan kehidupan remaja, misalnya sekolah ataupun orangtua. Menurut pandangan orang tua, anak-anak pada masa remaja masih belum siap dalam menghadapi tantangan dunia luar sehingga perlu dilindungi, sedangkan menurut para remaja masa itu merupakan masa pencarian atas keingintahuan (penasaran) 
yang dimiliki. Setiap remaja diharapkan dapat mengendalikan dan memiliki pengaturan diri yang baik agar dapat mengatasi dan menghadapi berbagai masalah di periode berikutnya, termasuk dalam memperoleh prestasi akademik yang baik (Gunarsa, 2010).

\section{Data Program for International Student} Assessment (PISA) menunjukkan bahwa prestasi anak usia remaja di Indonesia berada pada standar yang rendah dalam kemampuan matematika, sciences, dan membaca. Hal ini menunjukkan bahwa kemampuan anak usia remaja di Indonesia belum dikembangkan secara optimal. Permasalahan yang sering muncul adalah potensi akademik anak usia remaja yang tinggi atau berada di atas ratarata tidak menjadi jaminan untuk mendapatkan prestasi akademik yang tinggi pula. Berdasarkan data PISA pada tahun 2015 negara Indonesia mencapai skor rata-rata scient 403, skor rata-rata reading 397, skor rata-rata mathematic 386 , sementara skor rata-rata yang telah dicapai masih berada dibawah skor rata-rata OECD yaitu 493 (OECD, 2015). Hal ini mengindikasikan bahwa prestasi siswa Indonesia masih dibawah ratarata Negara yang lain, sehingga dibutuhkan dukungan dari keluarga, sekolah, dan pemerintah.

Berbagai faktor telah ditemukan sebagai faktor-faktor yang menentukan prestasi akademik remaja.diantaranya strategi pengaturan diri dalam belajar, pengaruh harapan orang tua dan motivasi intrinsik (Novita \& Latifah, 2014); jenis kelamin remaja dan teman sebaya (Zahra \& Hernawati, 2015); dukungan informasional dari orang tua (Indrawati \& Alfiasari, 2016). Pengetahuan kognitif dan strategi metakognitif diketahui belum cukup untuk meningkatkan prestasi akademik remaja (Pintrich \& De Groot, 1990). Prestasi akademik merupakan proses belajar untuk perubahan sehingga pencapaian kemampuan akan bertambah. Menurut Dariyo (2013), prestasi belajar ialah hasil pencapaian yang diperoleh seorang pelajar (siswa) setelah mengikuti ujian dalam suatu pelajaran tertentu dan dapat diwujudkan dalam laporan nilai yang tercantum dalam buku rapor atau kartu hasil studi (KHS). Chung (2000) mengatakan bahwa proses belajar bukan hanya dikontrol oleh aspek eksternal saja, melainkan juga dikontrol oleh aspek internal, seperti pengaturan diri dalam belajar (self regulated learning) yang di dalamnya terdapat komponen strategi.

Pintrich \& De Groot (1990) menyebutkan bahwa strategi pengaturan diri dalam belajar merupakan salah satu komponen dari pengaturan diri dalam belajar (self-regulated learning). Kegagalan pengaturan diri dalam belajar akan memengaruhi pencapaian prestasi akademiknya. Salmeron-Perez et al. (2010) menyatakan bahwa kemampuan penggunaan strategi pengaturan diri dalam belajar mulai muncul pada awal masa remaja. Pengaturan diri dalam belajar adalah pengaturan atau cara individu dalam menetapkan tujuan pembelajaran dengan mengendalikan, memonitor, dan mengatur perilaku mereka dalam menanggapi kondisi lingkungan yang spesifik untuk memenuhi tujuan yang sudah direncanakan. Penerapan pendekatan model pembelajaran selfregulated learning memberikan pengaruh positif signifikan terhadap motivasi belajar (Hidayat \& Budiman, 2000). Salmeron-Perez et al. (2010) mengatakan bahwa strategi pengaturan diri dalam belajar memiliki pengaruh langsung secara positif signifikan terhadap prestasi akademik. Hasil penelitian Novita dan Latifah (2014) memperlihatkan bahwa strategi pengaturan diri dalam belajar berperan sebagai mediator pengaruh harapan orang tua dan motivasi intrinsik terhadap prestasi akademik, sehingga orang tua dan guru harus mampu memunculkan motivasi intrinsik siswa sehingga siswa dapat melakukan strategi pengaturan diri dalam belajar secara baik untuk meningkatkan prestasi akademiknya.

Selain strategi pengaturan diri dalam belajar, motivasi merupakan faktor dari dalam diri remaja yang diduga dalam penelitian ini menentukan prestasi akademik remaja. Motivasi berhubungan positif signifikan dengan pengaturan diri dalam belajar (Hidayat \& Budiman, 2000; Novita \& Latifah, 2014), karena pengaturan diri bukan hanya terkait proses logika dan mental, melainkan juga kondisi emosional dan motivasi belajar (Salmeron-Perez et al., 2010). Motivasi merupakan suatu hal yang penting dalam proses belajar karena dapat menggerakkan organisme, mengarahkan tindakan, serta memilih tujuan belajar yang paling berguna bagi kehidupannya (Soemanto, 2006). Motivasi terbagi menjadi dua, yaitu motivasi intrinsik dan motivasi ekstrinsik. Motivasi intrinsik merupakan motivasi yang paling berpengaruh dalam proses belajar karena individu yang memiliki motivasi intrinsik tidak akan merasa terhambat oleh berbagai rintangan yang ada di sekitarnya (Santrock, 2003). Menurut Ryan dan Deci (2000), individu yang memiliki motivasi intrinsik akan menghasilkan kualitas belajar dan kreativitas 
yang lebih tinggi dibandingkan dengan motivasi ekstrinsik. Oleh karenanya, motivasi intrinsik perlu ditingkatkan agar dapat berinisiatif dengan minat dan kesenangan sebagai motivator dalam kegiatan belajar yang dapat meningkatkan prestasi akademiknya secara optimal. Pintrich dan De Groot (1990) menyatakan nilai intrinsik seseorang memiliki pengaruh yang sangat kuat terhadap penggunaan komponen strategi pengaturan diri dalam belajar (selfregulated learning strategies). Santrock (2003) menyebutkan bahwa motivasi berpengaruh tidak langsung terhadap prestasi akademik.

Selain dari diri remaja, keluarga juga memberikan peran dalam prestasi akademik anak. Kualitas gaya pengasuhan yang baik akan berdampak pada pengoptimalan strategi belajar, serta meningkatkan motivasi agar dapat mencapai prestasi akademik yang baik (Hastuti, 2006; Clark, 1983). Pengasuhan adalah perilaku orang tua terhadap anak agar dapat bertanggung jawab serta memberikan kontribusi sebagai anggota masyarakat, termasuk perilaku orang tua ketika menghadapi emosi anak, seperti menangis, agresif, berbohong atau menunjukkan kompetensi yang kurang dalam pendidikan (Brooks, 2001). Hasil penelitian Elmanora, Muflikhati, dan Alfiasari (2012) menunjukkan adanya pengaruh positif signifikan pendidikan ibu terhadap gaya pengasuhan orang tua, yang secara tidak langsung akan berpengaruh terhadap pencapaian prestasi akademik. Kecenderungan yang semakin menurun pada pola asuh akademik orang tua dikemukakan oleh Srinovita et al. (2012) seiring dengan bertambahnya usia anak. Hal ini diduga karena orang tua menganggap anak sudah dewasa dan mampu mengurus dirinya sendiri sehingga orang tua akan lebih memilih untuk bekerja dan menyibukkan diri di luar rumah.

Proses pengaturan diri dalam belajar erat kaitannya dengan perilaku pengasuhan orang tua yang terdiri dari otoritatif, otoriter, dan permisif (Purdie et al., 2004). Menurut Baumrind (1991), gaya pengasuhan merupakan bentuk-bentuk perlakukan orang tua ketika berinteraksi dengan anak atau remaja, yang terdiri atas tiga kategori yaitu otoritatif, otoriter, dan permisif. Dimensi pengasuhan positif berkorelasi dengan pengaturan diri, kompetensi akademik, sosial, prestasi akademik, komitmen untuk sekolah, kontrol diri, dan harga diri. Namun ketika anak mengalami penolakan orang tua, kekacauan dan pemaksaan, dan tidak memperoleh dukungan, anak-anak tersebut cenderung menghindari untuk bersosialisasi, memiliki hasil akademik negatif, terlibat dalam penggunaan narkoba lebih sering, dan memiliki masalah perilaku (Skinner, Sandy, \& Tatiana, 2005). Gaya pengasuhan otoritatif berhubungan positif dengan motivasi sedangkan gaya pengasuhan otoriter berhubungan negatif dengan motivasi (Cramer, 2002). Gaya pengasuhan otoritatif dan motivasi menjadi prediktor yang signifikan terhadap prestasi akademik remaja (Turner et al., 2009; Tavani \& Losh, 2003). Prestasi akademik merupakan salah satu output pendidikan yang penting untuk ditingkatkan. Megawangi, Latifah, dan Dina (2008) mengklasifikasikan aspek-aspek potensi manusia berupa aspek emosi, akademik, dan sosial yang perlu dikembangkan melalui pendidikan. Berdasarkan pemaparan tersebut, penelitian ini bertujuan untuk menganalisis pengaruh karakteristik keluarga, gaya pengasuhan yang diberikan orang tua, motivasi, dan strategi pengaturan diri dalam belajar terhadap prestasi akademik remaja.

\section{METODE}

Desain yang digunakan dalam penelitian ini adalah cross-sectional study, dengan pemilihan lokasi menggunakan metode cluster random sampling berdasarkan pertimbangan bahwa orang hidup dalam kelompok alami (desa, kota) dan berpartisipasi dalam kegiatan lembaga seperti sekolah. SMPN X di Kota Bogor dan SMPN Y di Kabupaten Bogor adalah dua sekolah terpilih tempat penelitian dilakukan. Data sekolah SMPN di wilayah Bogor didapatkan dari Dinas Pendidikan Kota dan Kabupaten Bogor.

Populasi penelitian ini adalah seluruh remaja di wilayah Bogor dan kerangka contoh penelitian adalah remaja yang berada di kelas VIII SMPN X Kota Bogor dan SMPN $Y$ Kabupaten Bogor. Contoh yang dipilih adalah siswa kelas VIII dengan berbagai pertimbangan, diantaranya siswa kelas VIII tidak disibukkan dengan berbagai rutinitas kegiatan belajar dalam menghadapi Ujian Akhir Nasional dan sudah lebih lama pengalamannya di sekolah dibandingkan siswa kelas VII. Pengambilan contoh tersebut dilakukan dengan menggunakan teknik cluster proportional random sampling. Contoh yang diambil adalah seluruh siswa kelas VIII-A dan VIII-G di SMPN X Kota Bogor, serta VIII-D dan VIII-E di SMPN Y Kabupaten Bogor. Penelitian ini melibatkan 149 siswa, yaitu 84 siswa mewakili Kota Bogor, dan 65 siswa mewakili Kabupaten Bogor. Proporsi yang berbeda 
dikarenakan jumlah siswa kelas VIII yang berbeda pada masing-masing sekolah yang terpilih.

Data primer merupakan hasil dari pelaporan diri (self-administered) dengan alat bantu kuesioner, meliputi karakteristik anak (jenis kelamin, dan urutan kelahiran) dengan skala data nominal; karakteristik keluarga (usia orang tua, lama pendidikan orang tua, besar keluarga, dan pendapatan per kapita) dengan skala data rasio; gaya pengasuhan, motivasi, dan strategi pengaturan diri anak usia remaja dengan skala jawaban di kuesioner adalah data ordinal. Data sekunder terdiri dari data siswa dan data orang tua siswa, serta nilai rapor siswa kelas VIII semester awal/ganjil di SMPN X dan SMPN Y. Prestasi akademik dilihat dari nilai rapor siswa dengan skala data rasio.

Gaya pengasuhan orang tua diukur menggunakan kuesioner yang dikembangkan oleh Alfiasari, Latifah dan Wulandari (2011) yang terdiri atas 30 pernyataan dengan skala Likert 1-4, yaitu skala 1=tidak pernah, $2=$ hampir tidak pernah, $3=$ sering, dan $4=$ sangat sering/selalu dengan nilai Cronbach's alpha pada penelitian ini sebesar 0,636. Motivasi menggunakan Intrinsic Motivation Inventory (IMI) dari Ryan (1982) dan dimodifikasi oleh peneliti. Motivasi diklasifikasikan ke dalam enam dimensi penilaian, yaitu interest/enjoyment, perceived competence, effort/importance, pressure/tension, perceived choice, dan value/usefulness (Ryan \& Deci, 2000). Penilaian motivasi berasal dari dalam dirinya sendiri, terdiri dari 35 pernyataan yang kemudian dimodifikasi menjadi 27 pernyataan dengan skala Likert 1-4, yaitu 1=sangat tidak setuju, 2=tidak setuju, 3=setuju, dan $4=$ sangat setuju dengan nilai Cronbach's alpha pada penelitian ini adalah 0,835. Strategi pengaturan diri dalam belajar mengacu pada Motivated Strategies for Learning Questionnaire (MSLQ) yang telah dikembangkan oleh Pintrich et al. (1991). Kuesioner ini berisi tentang penggunaan strategi belajar terkait dengan perilaku belajar dan pencapaian prestasi siswa, terdiri dari 50 pernyataan yang dikembangkan menjadi 37 pernyataan dengan skala Likert 1-4, yaitu $1=$ sangat tidak sesuai, $2=$ tidak sesuai, $3=$ sesuai, dan $4=$ sangat sesuai dengan nilai Cronbach's alpha pada penelitian ini sebesar 0,845 .

Proses pengolahan data yang dilakukan adalah editing, coding, scoring, entering data, dan cleaning data. Konsistensi kuesioner penelitian ini dilihat dengan uji validitas dan reliabilitas menggunakan metode Cronbach's alpha. Data karakteristik anak terdiri dari jenis kelamin dan urutan kelahiran contoh. Data jenis kelamin dibedakan menjadi dua, yaitu laki-laki dan perempuan, sedangkan data urutan kelahiran tidak dikategorikan. Data karakteristik keluarga terdiri dari usia orang tua, lama pendidikan orang tua, besar keluarga, dan pendapatan per kapita. Data usia orang tua dibedakan menjadi tiga kategori, yaitu dewasa awal (18-40 tahun), dewasa madya (41-60 tahun, dan dewasa lanjut (61-kematian) (Hurlock, 1980). Data lama pendidikan orang tua dibagi menjadi dua kategori, yaitu pendidikan yang ditempuh selama 0-12 tahun dan di atas 12 tahun. Data besar keluarga dibagi menjadi 3 kategori, yaitu keluarga besar ( $\geq 8$ orang), keluarga sedang (5-7 orang), dan keluarga kecil ( $\leq 4$ orang) (BKKBN, 1998). Data pendapatan per kapita dibedakan berdasarkan garis kemiskinan di Kota maupun Kabupaten Bogor, yaitu di atas garis kemiskinan Kota Bogor (>Rp305.870,00/kapita/bulan), di bawah garis kemiskinan Kota Bogor ( $\leq$ Rp305.870,00/kapita/bulan), di atas garis kemiskinan Kabupaten Bogor (>Rp235.682,00/kapita/bulan), dan di bawah garis kemiskinan Kabupaten Bogor ( $\leq$ Rp235.682,00/kapita/bulan) (BPS, 2011).

Masing-masing variabel penelitian diberikan skor pada setiap pertanyaan di kuesioner. Kemudian skor total dari masing-masing variabel ditransformasikan menjadi indeks. Hal ini dilakukan agar memperoleh nilai minimum 0 dan nilai maksimum 100 dan untuk menyamakan satuan agar perbandingan pengkategorian data setiap variabel seragam. Selanjutnya indeks dikategorikan menjadi tiga kategori, yaitu tinggi $(80,0-100,0)$, sedang $(60,0-80,0)$, dan rendah $(00,0-60,0)$. Selain itu, peneliti juga menggunakan rapor siswa kelas VIII semester satu yang diperoleh dari pihak sekolah terkait. Nilai rapor contoh tersebut akan dirata-ratakan, dan skor yang didapat dirata-ratakan kembali dengan keseluruhan nilai rata-rata contoh dan diubah ke dalam nilai IP dengan rumus sebagai berikut: nilai $\mathrm{IP}=(\mathrm{X} / 100 \times 4)$, dengan nilai $\mathrm{IP}$ : nilai contoh yang diperoleh $\mathrm{X}$ :nilai rapor contoh. Setelah itu, nilai tersebut dikategorikan berdasarkan Permendikbud (2013), yaitu kurang $(0,00$ $2,49)$, cukup $(2,50-2,99)$, baik $(3,00-3,49)$, dan sangat baik $(3,50-4,00)$.

Analisis deskriptif pada penelitian ini digunakan untuk melihat frekuensi, rataan, 
nilai maksimum, nilai minimum, dan standar deviasi yang menggambarkan karakteristik anak, karakteristik keluarga, gaya pengasuhan, motivasi, strategi pengaturan diri, dan prestasi akademik. Sebelum melakukan uji regresi linear berganda, peneliti harus memenuhi syarat-syarat terlebih dahulu, yaitu dengan melakukan uji asumsi klasik yang terdiri dari empat macam, yaitu uji normalitas, uji multikolinieritas, uji heteroskedastisitas, dan uji autokorelasi. Sesuai tujuan, penelitian ini menduga dalam model regresinya bahwa prestasi akademik remaja dipengaruhi oleh karakteristik anak, karakteristi keluarga, gaya pengasuhan, motivasi, dan strategi pengaturan diri dalam belajar.

\section{HASIL}

\section{Karakteristik Anak dan Keluarga}

Hasil penelitian memperlihatkan bahwa sekitar enam dari sepuluh remaja dalam penelitian ini merupakan remaja perempuan $(59,1 \%)$ dan sisanya laki-laki (40,9\%). Sementara itu, empat dari sepuluh remaja (42,3\%) merupakan anak pertama. Persentase terbesar ayah dan ibu remaja berada pada kategori usia dewasa madya (41-60 tahun), yaitu 81,2 persen untuk ayah dan 57,0 persen untuk ibu. Selain itu, hampir dua pertiga ayah $(66,4 \%)$ dan hampir empat perlima ibu $(79,2 \%)$ remaja mempunyai tingkat pendidikan di bawah 12 tahun. Proporsi terbesar keluarga remaja memiliki pendapatan per kapita di atas garis kemiskinan $(75,8 \%)$ dan lebih dari satu perdua remaja tergolong ke dalam keluarga sedang dengan anggota keluarga berjumlah 57 orang $(56,4 \%)$.

\section{Gaya Pengasuhan}

Tabel 1 menunjukkan bahwa sebesar 89,3 persen remaja memersepsikan gaya pengasuhan otoritatif diperoleh dari orang tua dengan rataan tertinggi diantara ketiga gaya pengasuhan tersebut ditemukan pada gaya otoritatif $(66,02)$. Hal ini ditunjukkan dengan adanya remaja yang merasa jika orang tua melarang melakukan sesuatu juga diiringi dengan penjelasan yang baik tentang larangan yang diterapkan; orang tua dan remaja sering bekerja sama dalam memutuskan kepentingan masa depan remaja; remaja dan orang tua dapat berdiskusi dan mendengarkan keluhan remaja tentang apapun; orang tua remaja perhatian yang ditunjukkan dengan rajin bertanya hal yang dialami remaja dan sering menghubungi remaja untuk bertanya tentang kondisi remaja; orang tua sering memberikan peringatan sebelum menetapkan hukuman dan menetapkan sanksi jika melakukan kesalahan; serta orang tua sering menoleransi perbedaan pendapat diantara orang tuaremaja.

Meskipun begitu, penelitian ini masih adanya remaja yang memersepsikan bahwa orang tuanya menggunakan gaya pengasuhan otoriter (Tabel 1). Berdasarkan sebaran jawaban remaja, ditemukan adanya orang tua yang masih memberikan hukuman tanpa penjelasan, menuntut prestasi yang baik dari anak, membatasi dalam bergaul, serta tidak pernah mengikuti les tambahan. Sementara itu, pada remaja yang memersepsikan orang tuanya menerapkan gaya pengasuhan permisif ditunjukkan oleh sebaran jawaban remaja yang menilai orang tuanya tidak pernah menerapkan aturan apapun di rumah atau di sekolah, membebaskan pergaulan tanpa batasan, serta membebaskan pergi kemanapun sesuai keinginan remaja.

\section{Motivasi}

Hasil penelitian menunjukkan bahwa lebih dari separuh remaja memiliki motivasi kategori sedang $(53,0 \%)$ dengan rata-rata skor sebesar 60,87 (Tabel 2). Hal ini berarti lebih dari separuh remaja memiliki motivasi yang cukup untuk melibatkan diri dalam aktivitas belajar. Motivasi diklasifikasikan ke dalam enam dimensi penilaian, yaitu interest/enjoyment, perceived competence, effort/importance, pressure/tension, perceived choice, dan value/usefulness (Ryan \& Deci, 2000).

Dimensi interest/enjoyment. Hasil penelitian memperlihatkan bahwa lebih dari satu perdua remaja terkategori rendah $(56,4 \%)$ dalam dimensi interest/enjoyment. Artinya lebih dari separuh remaja tidak memiliki ketertarikan terhadap semua kegiatan di kelas dan menganggap bahwa mengerjakan tugas sekolah adalah hal yang tidak menyenangkan. Hasil ini juga mengindikasikan bahwa motivasi remaja masih kurang optimal sehingga perlu dilakukan cara lain untuk menarik motivasi remaja dalam hal belajar dan mengerjakan tugas.

Tabel 1 Sebaran remaja berdasarkan gaya pengasuhan orang tua

\begin{tabular}{llll}
\hline \multicolumn{1}{c}{ Gaya } & \multicolumn{2}{c}{ Frekuensi } & Rata-rata \pm \\
\cline { 2 - 3 } pengasuhan & $\mathrm{n}$ & $\%$ & SD \\
\hline Otoritatif & 133 & 89,3 & $66,02 \pm 15,53$ \\
Otoriter & 12 & 8,0 & $35,17 \pm 14,70$ \\
Permisif & 4 & 2,7 & $29,62 \pm 12,48$ \\
\hline
\end{tabular}


Dimensi perceived competence. Penelitian ini menemukan bahwa hampir separuh remaja memiliki motivasi dimensi perceived competence pada kategori rendah $(48,3 \%)$ dan sedang $(45,6 \%)$ yang tidak berbeda jauh. Artinya mayoritas remaja masih merasa kurang dalam kompetensi diri, namun merasa cukup mampu untuk mengerjakan tugas sekolah dengan baik. Hal ini juga berarti remaja merasa kurang dalam kompetensi diri perlu untuk ditingkatkan lagi sehingga dapat mencapai kompetensi yang optimal. Kompetensi yang ada saat ini sudah cukup dapat dilakukan dengan baik, tetapi kurang mendapatkan tantangan.

Dimensi effort/importance. Hasil penelitian memperlihatkan bahwa lebih dari separuh remaja memiliki dimensi effort/importance pada kategori sedang $(55,7 \%)$. Hal ini berarti lebih dari separuh remaja sudah cukup untuk berusaha memahami setiap materi pelajaran di kelas. Remaja juga merasa penting untuk mengerjakan tugas sekolah dengan baik.

Dimensi pressure/tension. Tabel 2 menunjukkan lebih dari separuh remaja memiliki kategori sedang $(51,7 \%)$ dalam dimensi pressure/tension. Hal ini berarti lebih dari separuh remaja tidak pernah merasa gugup pada saat mengerjakan ujian. Meskipun begitu, remaja juga merasa tertekan apabila tidak mengerjakan ujian dengan baik.

Dimensi perceived choice. Penelitian ini menemukan bahwa sebagian besar remaja memiliki dimensi perceived choice pada kategori rendah sebesar 85,9 persen. Artinya masih banyak remaja yang merasa mengerjakan tugas sekolah adalah suatu keharusan. Adapun hal ini menunjukkan remaja terpaksa mengerjakan tugas dikarenakan takut dengan guru ataupun takut dengan nilainya kurang memuaskan. Remaja juga tidak memiliki pilihan lain selain melakukan kegiatan belajar di kelas. Kondisi ini menunjukkan terbatasnya pilihan remaja dalam mengembangkan dirinya.

Dimensi value/usefulness. Hasil pada Tabel 2 menunjukkan bahwa sebagian besar remaja memiliki dimensi value/usefulness pada kategori sedang $(72,5 \%)$. Hal ini berarti sekitar tiga perempat remaja sudah cukup menyadari nilai atau kegunaan dari proses belajar meskipun belum sangat tinggi kesadaran akan nilai ini. Hal ini dapat terlihat dari remaja yang telah menyadari bahwa kegiatan di kelas adalah kegiatan yang penting untuk dilakukan. Hal tersebut dilakukan remaja agar dapat meningkatkan prestasi di sekolah. Selain itu, remaja telah memandang bahwa mendengarkan penjelasan guru dapat membantu dalam memahami materi pelajaran. Nilai tugas dipandang remaja dalam perspektif bahwa ketika remaja mengerjakan tugas sekolah maka akan dapat meningkatkan kebiasaan dan konsentrasi belajar.

\section{Strategi Pengaturan Diri dalam Belajar}

Tabel 3 menunjukkan bahwa sekitar tujuh dari sepuluh remaja $(73,2 \%)$ memiliki strategi pengaturan diri dalam belajar terkategori rendah dengan skor rata-rata sebesar 54,70. Hal ini berarti tujuh dari sepuluh remaja dalam penelitian ini masih belum memiliki strategi pengaturan diri dalam belajar yang tepat. Strategi pengaturan diri dalam belajar terbagi ke dalam sembilan dimensi penilaian, yaitu rehearsal, elaboration, organization, critical thinking, metacognitive self-regulation, time/study environmental management, effort regulation, peer learning, dan help seeking (Pintrich et al., 1991). Hasil menunjukkan hampir seluruh dimensi penilaian berada pada kategori rendah, kecuali dimensi effort regulation $(57,0 \%)$, dan peer learning $(51,7 \%)$ yang proporsi terbesarnya berada pada kategori sedang.

Tabel 2 Sebaran remaja berdasarkan dimensi motivasi serta nilai minimum, maksimum, rata-rata, dan standar deviasi variabel motivasi

\begin{tabular}{|c|c|c|c|c|c|}
\hline \multirow[b]{2}{*}{ Motivasi } & \multicolumn{3}{|c|}{$\begin{array}{l}\text { Kategori }(\%) \\
\end{array}$} & \multirow[b]{2}{*}{$\begin{array}{l}\text { Min- } \\
\text { Maks }\end{array}$} & \multirow[b]{2}{*}{$\begin{array}{c}\text { Rata- } \\
\text { rata } \pm \\
\text { SD }\end{array}$} \\
\hline & $\begin{array}{l}\text { Tinggi } \\
(80,0- \\
100,0) \\
\end{array}$ & $\begin{array}{l}\text { Sedang } \\
60,0- \\
30,0) \\
\end{array}$ & $\begin{array}{l}\text { Rendah } \\
(00,0- \\
60,0) \\
\end{array}$ & & \\
\hline $\begin{array}{l}\text { Interest/ } \\
\text { enjoyment }\end{array}$ & 1,3 & 42,3 & 56,4 & $\begin{array}{c}13,33 \\
- \\
93,33\end{array}$ & $\begin{array}{c}53,29 \pm \\
14,55\end{array}$ \\
\hline $\begin{array}{l}\text { Perceived } \\
\text { competence }\end{array}$ & 6,0 & 45,6 & 48,3 & $\begin{array}{c}33,33 \\
- \\
91,67\end{array}$ & $\begin{array}{c}62,70 \pm \\
10,86\end{array}$ \\
\hline $\begin{array}{l}\text { Effort/ } \\
\text { importance }\end{array}$ & 20,8 & 55,7 & 23,5 & $\begin{array}{c}33,33 \\
- \\
100,0 \\
0\end{array}$ & $\begin{array}{r}70,36 \pm \\
12,87\end{array}$ \\
\hline $\begin{array}{l}\text { Pressure/ } \\
\text { tension }\end{array}$ & 4,7 & 51,7 & 43,6 & $\begin{array}{c}22,22 \\
- \\
100,0 \\
0\end{array}$ & $\begin{array}{c}61,52 \pm \\
15,58\end{array}$ \\
\hline $\begin{array}{l}\text { Perceived } \\
\text { choice }\end{array}$ & 0,7 & 13,4 & 85,9 & $\begin{array}{c}25,00 \\
- \\
83,33\end{array}$ & $\begin{array}{c}51,90 \pm \\
11,09\end{array}$ \\
\hline $\begin{array}{l}\text { Value/ } \\
\text { usefulness }\end{array}$ & 7,4 & 72,5 & 20,1 & $\begin{array}{c}40,00 \\
- \\
100,0 \\
0\end{array}$ & $\begin{array}{c}66,17 \pm \\
11,83\end{array}$ \\
\hline $\begin{array}{l}\text { Total } \\
\text { Motivasi }\end{array}$ & 2,7 & 53,0 & 44,3 & $\begin{array}{c}38,67 \\
- \\
84,00 \\
\end{array}$ & $\begin{array}{c}60,87 \pm \\
9,06\end{array}$ \\
\hline
\end{tabular}


Dimensi rehearsal. Sebagian besar remaja sebesar 75,8 persen berada pada kategori rendah pada dimensi rehearsal. Hal ini berarti sebagian besar remaja masih merasa kurang dalam pemahaman suatu informasi sehingga mengulang kembali materi yang telah disampaikan. Remaja melakukan hal tersebut dengan membuat daftar yang harus dipelajari, seperti kata kunci untuk mengingat inti materi pelajaran.

Dimensi elaboration. Penelitian menemukan bahwa sekitar tiga dari lima remaja berada pada kategori rendah $(65,8 \%)$ pada dimensi elaboration. Artinya, tiga dari lima remaja dalam penelitian ini belum mampu menyimpan informasi jangka panjang dengan menghubungkan beberapa informasi yang harus dipelajari, seperti menghubungkan pengetahuan dari satu materi ke materi lainnya. Adapun hal inimenunjukkan bahwa cara belajar remaja masih terpisah-pisah sehingga belum dapat dikaitkan dengan pelajaran yang lainnya.

Dimensi organization. Hasil pada Tabel 3 menunjukkan bahwa sebagian besar remaja sebesar 82,6 persen memiliki kategori rendah pada dimensi organization. Hal ini menunjukkan bahwa sebagian besar remaja belum mampu memilih informasi yang sesuai dengan strategi belajar yang digunakan. Remaja belum membuat catatan-catatan penting, diagram atau tabel, serta poin-poin penting dari materi yang dipelajari untuk memudahkan dalam proses belajar.

Dimensi critical thinking. Hasil penelitian menemukan bahwa hampir tujuh dari sepuluh remaja $(68,5 \%)$ terkategori rendah untuk dimensi critical thinking. Artinya, kemampuan remaja untuk menerapkan pengetahuan yang dimilikinya sebagai usaha dalam memecahkan suatu masalah masih belum berkembang secara optimal. Hal ini ditunjukkan dalam hal memahami materi pelajaran dengan bereksperimen atau mengembangkan ide-ide kreatif masih tergolong rendah.

Dimensi metacognitive self-regulation. Penelitian menunjukkan bahwa hampir 80 persen remaja kategori rendah pada dimensi metacognitive self-regulation. Hasil ini ditunjukkan dengan lebih dari tiga perdua remaja tidak terbiasa membaca materi terlebih dahulu dan membuat pertanyaan sebelum diajarkan di kelas. Remaja juga sering merasa tidak memahami materi atau pelajaran yang telah diajarkan di kelas, sehingga ketika di kelas baru mengetahui materi tersebut.
Tabel 3 Sebaran remaja berdasarkan dimensi serta nilai minimum, maksimum, ratarata, dan standar deviasi variabel strategi pengaturan diri dalam belajar

\begin{tabular}{|c|c|c|c|c|c|}
\hline $\begin{array}{l}\text { Strategi } \\
\text { pengaturan } \\
\text { diri }\end{array}$ & $\begin{array}{l}\frac{\mathrm{K}}{\mathrm{K}} \\
\text { Tinggi } \\
(80,0- \\
100,0)\end{array}$ & $\begin{array}{l}\text { ategori } \\
\text { Sedang } \\
(60,0- \\
80,0)\end{array}$ & $\begin{array}{l}\frac{\%)}{\text { Rendah }} \\
(00,0- \\
60,0)\end{array}$ & $\begin{array}{l}\text { Min- } \\
\text { Maks }\end{array}$ & $\begin{array}{l}\text { Rata- } \\
\text { rata } \\
\text { SD }\end{array}$ \\
\hline Rehearsal & 2,7 & 21,5 & 75,8 & \multirow{9}{*}{$\begin{array}{c}16,67- \\
83,33 \\
22,22- \\
88,89 \\
0,00- \\
77,78 \\
11,11- \\
88,89 \\
20,83- \\
83,33 \\
23,81- \\
90,48 \\
33,33- \\
100,00 \\
22,22- \\
88,89 \\
22,22- \\
100,00 \\
\end{array}$} & \multirow{3}{*}{$\begin{array}{c}50,95 \pm \\
15,12 \\
55,86 \pm \\
14,95 \\
46,61 \pm \\
15,96\end{array}$} \\
\hline Elaboration & 5,4 & 28,9 & 65,8 & & \\
\hline Organization & 0,0 & 17,4 & 82,6 & & \\
\hline $\begin{array}{l}\text { Critical } \\
\text { thinking }\end{array}$ & 2,0 & 29,5 & 68,5 & & $\begin{array}{c}51,98 \pm \\
16,30\end{array}$ \\
\hline$M S R$ & 1,3 & 19,5 & 79,2 & & $\begin{array}{c}51,85 \pm \\
11,44\end{array}$ \\
\hline TEM/SEM & 3,4 & 45,6 & 51,0 & & $\begin{array}{c}59,06 \pm \\
11,38\end{array}$ \\
\hline $\begin{array}{l}\text { Effort } \\
\text { regulation }\end{array}$ & 14,8 & 57,0 & 28,2 & & $\begin{array}{c}68,91 \pm \\
14,44\end{array}$ \\
\hline $\begin{array}{l}\text { Peer } \\
\text { learning }\end{array}$ & 4, & 51,7 & 43,6 & & $\begin{array}{c}62,72 \pm \\
13,05\end{array}$ \\
\hline $\begin{array}{l}\text { Help } \\
\text { seeking }\end{array}$ & 0,7 & 48,3 & 51,0 & & $\begin{array}{c}60,78 \pm \\
11,00\end{array}$ \\
\hline $\begin{array}{l}\text { Total } \\
\text { Strategi } \\
\text { pengaturan } \\
\text { diri } \\
\end{array}$ & 0,0 & 26,8 & 73,2 & $\begin{array}{l} \\
28,48- \\
79,41\end{array}$ & $\begin{array}{c}54,70 \pm \\
9,15\end{array}$ \\
\hline & & & & & \\
\hline
\end{tabular}

\section{Dimensi time/study environmental} management. Hasil yang tersaji pada Tabel 3 menunjukkan bahwa separuh remaja terkategori rendah $(51,0 \%)$ pada dimensi time/study environmental management. Hal ini berarti pengaturan/pengelolaan waktu dan lingkungan belajar remaja masih belum dilaksanakan dengan optimal. Temuan ini diperlihatkan dengan remaja yang masih suka menunda-nunda waktu bahkan tidak menyempatkan waktu untuk belajar. Berdasarkan hasil penelitian tersebut, masih diperlukan kerja sama dengan orang tua untuk mendorong remaja siswa mampu mengatur waktunya dengan baik.

Tabel 4 Sebaran remaja berdasarkan kategori serta nilai minimum, maksimum, ratarata, dan standar deviasi variabel prestasi akademik remaja

\begin{tabular}{lcc}
\hline \multirow{2}{*}{ Prestasi Akademik } & \multicolumn{2}{c}{ Frekuensi } \\
\cline { 2 - 3 } & $\mathrm{n}$ & $\%$ \\
\hline Kurang $(0,00-2,49)$ & 0 & 0,0 \\
Cukup $(2,50-2,99)$ & 7 & 4,7 \\
Baik $(3,00-3,49)$ & 142 & 95,3 \\
Sangat baik & 0 & 0,0 \\
$(3,50-4,00)$ & & \\
\hline Total & 149 & 100,0 \\
\hline Min-Maks & \multicolumn{2}{c}{$2,58-3,44$} \\
Rata-rata \pm SD & $3,15 \pm 0,11$ \\
\hline
\end{tabular}


Dimensi effort regulation. Hasil penelitian menunjukkan bahwa lebih dari separuh remaja berada pada kategori sedang $(57,0 \%)$ dalam dimensi effort regulation. Artinya, lebih dari separuh remaja sudah dapat mengontrol usaha dan perhatiannya dalam menghadapi tugas meskipun remaja merasa tugas atau pelajaran kurang menarik dan merasa ada gangguan belajar. Remaja menilai dirinya tetap dapat fokus seperti tetap belajar ketika mendapatkan materi pelajaran yang sulit untuk dipahami.

Dimensi peer learning. Data pada Tabel 3 menunjukkan bahwa lebih dari separuh remaja memiliki dimensi peer learning kategori sedang sebesar 51,7 persen. Hal ini berarti lebih dari separuh remaja sudah mampu bekerja sama dengan teman. Temuan tersebut diperlihatkan dengan adanya remaja yang membantu teman dalam memahami materi pelajaran, mengerjakan tugas bersama teman, dan membahas materi pelajaran yang sulit ketika sedang belajar kelompok.

Dimensi help seeking. Pada dimensi help seeking, lebih dari separuh remaja terkategori rendah (51,0\%). Proporsi tersebut menunjukkan bahwa masih banyak remaja yang mencoba menyelesaikan kesulitan belajarnya sendiri tanpa bantuan orang lain. Hal ini berarti remaja juga ingin menunjukkan bahwa dirinya bisa dan mampu dalam mengerjakan tugasnya.

\section{Prestasi Akademik}

Prestasi akademik adalah tingkat keberhasilan seseorang yang ditunjukkan melalui pencapaian prestasi di bidang akademik. Hasil penelitian menunjukkan bahwa mayoritas remaja berada pada kategori baik $(95,3 \%)$. Hal ini berarti lebih dari 95 persen remaja memiliki nilai capaian belajar yang berkisar antara 3,003,49 . Sementara itu tidak ditemukan adanya prestasi akademik remaja dalam penelitian ini yang terkategori kurang ataupun sangat baik.

Pengaruh Karakteristik Keluarga, Gaya Pengasuhan, dan Strategi Pengaturan Diri dalam Belajar terhadap Prestasi Akademik Remaja

Tabel 5 menunjukkan analisis regresi model yang berpengaruh terhadap prestasi akademikModel ini memiliki nilai Adjusted $R$ square sebesar 0,134 , yang artinya 13,4 persen prestasi akademik dipengaruhi oleh beberapa variabel dalam model dan 86,6 persen dipengaruhi variabel lain di luar model (Tabel 5). Lama pendidikan ibu memiliki pengaruh negatif signifikan terhadap prestasi akademik remaja $(\beta=-0,239$, pvalue $=0,003)$. Artinya, ibu yang pendidikannya sederajat SMA atau di bawahnya lebih berpeluang dalam meningkatkan skor prestasi akademik remaja sebesar 0,239. Hal ini diduga karena sebagian besar ibu dalam penelitian ini berpendidikan SMA dan tidak bekerja (sebagai ibu rumah tangga) sehingga memiliki lebih banyak waktu untuk mendampingi anakanaknya dalam meningkatkan prestasi akademik.

Selain itu, penelitian ini juga menemukan bahwa gaya pengasuhan otoriter memiliki pengaruh negatif signifikan terhadap prestasi akademik remaja $(\beta=-0,031, p$-value $=0,041)$. Artinya setiap peningkatan skor satu poin pada gaya pengasuhan otoriter berpengaruh terhadap penurunan skor prestasi akademik sebesar 0,031. Sementara itu, gaya pengasuhan otoritatif memiliki pengaruh positif signifikan terhadap prestasi akademik remaja $(\beta=0,034, p$-value $=0,020)$, yang berarti setiap peningkatan skor satu poin pada gaya pengasuhan otoritatif yang diterapkan orang tua maka akan meningkatkan skor prestasi akademiknya sebesar 0,034. Hasil lain dalam penelitian ini adalah strategi pengaturan diri dalam belajar memiliki pengaruh positif signifikan terhadap prestasi akademik remaja $(\beta=0,084, \quad p$-value $=0,001)$. Hal ini berarti peningkatan jumlah strategi pengaturan diri yang digunakani remaja maka akan meningkatkan skor prestasi akademiknya sebesar 0,084 .

Tabel 5 Koefisien uji regresi karakteristik keluarga, gaya pengasuhan, dan strategi pengaturan diri dalam belajar terhadap prestasi akademik

\begin{tabular}{|c|c|c|c|}
\hline \multirow{2}{*}{ Variabel } & \multicolumn{2}{|c|}{ Prestasi Akademik } & \multirow{2}{*}{ Sig. } \\
\hline & $\mathrm{B}$ & $\mathrm{B}$ & \\
\hline Konstanta & 78,289 & & 0,000 \\
\hline Usia ibu & $-0,045$ & $-0,091$ & 0,239 \\
\hline $\begin{array}{l}\text { Lama pendidikan } \\
\text { ibu }\end{array}$ & $-0,239$ & $-0,240$ & $0,003^{\star *}$ \\
\hline Besar keluarga & $-0,099$ & $-0,044$ & 0,581 \\
\hline $\begin{array}{l}\text { Pendapatan per } \\
\text { kapita }\end{array}$ & $-1,954$ & $-0,079$ & 0,314 \\
\hline $\begin{array}{l}\text { Gaya pengasuhan } \\
\text { otoritatif }\end{array}$ & 0,034 & 0,188 & $0,020^{*}$ \\
\hline $\begin{array}{l}\text { Gaya pengasuhan } \\
\text { otoriter }\end{array}$ & $-0,031$ & $-0,162$ & $0,041^{*}$ \\
\hline $\begin{array}{l}\text { Gaya pengasuhan } \\
\text { permisif }\end{array}$ & 0,005 & 0,022 & 0,781 \\
\hline $\begin{array}{l}\text { Strategi } \\
\text { pengaturan diri }\end{array}$ & 0,084 & 0,276 & $0,001^{*}$ \\
\hline $\mathrm{N}$ & & & 149 \\
\hline R2 adjusted & & & 0,134 \\
\hline
\end{tabular}




\section{PEMBAHASAN}

Perilaku orang tua dalam bentuk gaya pengasuhan cenderung berpengaruh terhadap tumbuh kembang anak. Dwairy et al. (2006) mengatakan bahwa gaya pengasuhan yang diterapkan orang tua memiliki peranan dalam menentukan kualitas remaja di berbagai aspek perkembangannya. Karakteristik keluarga dapat memengaruhi perilaku orang tua dalam bentuk pengasuhan karena setiap keluarga memiliki perbedaan nilai-nilai dan norma yang diterapkan kepada anak. Hasil penelitian Elmanora, Muflikhati, dan Alfiasari (2012) pendidikan ibu berhubungan gaya pengasuhan. Sebagian besar remaja dalam penelitian ini memersepsikan gaya pengasuhan otoritatif. Gaya pengasuhan yang diberikan oleh orang tua dan pemberian kesempatan untuk mengembangkan sikap agar dapat berdiri sendiri menentukan tinggi rendahnya motivasi anak (Winkel, 2007).

Motivasi yang dimiliki seorang remaja merupakan pondasi keberhasilan dalam berbagai bidang. Perilaku orang tua dalam menjadikan anak paham dan sadar pentingnya belajar dan menjadi orang yang berpengetahuan adalah salah satu contoh perilaku yang dapat dilakukan orang tua untuk meningkatkan motivasi remaja. Santrock (2003) mengatakan bahwa kualitas pola interaksi yang dihasilkan dalam gaya pengasuhan otoritatif menimbulkan keberanian, kemandirian, dan motivasi anak dalam menghadapi masa depannya sehingga akan berpengaruh dalam peningkatan motivasi berupa dukungan atau kekuatan. Sebaliknya, Baumrind (1972) mengatakan bahwa gaya pengasuhan permisif akan menghasilkan anak yang rendah kontrol diri, kurang bertanggung jawab, dan tidak terampil dalam menghadapi masalah.

Motivasi merupakan salah satu aspek penting dalam proses strategi pengaturan diri dalam belajar. Kemampuan strategi pengaturan diri seseorang tidak akan dapat berkembang dengan sendirinya karena dibutuhkan dorongan atau keinginan dari dalam diri sendiri atau yang biasa disebut dengan motivasi (Santrock, 2003; Inayah, 2013). Motivasi berpengaruh positif signifikan terhadap strategi pengaturan diri dalam belajar (Pintrich \& De Groot, 1990; Metallidou \& Vlachou, 2010; Hidayat \& Budiman, 2000). Menurut Metallidou dan Vlachou (2010), siswa yang termotivasi secara intrinsik akan menjaga ketertarikan terhadap materi pelajaran, serta mencari informasi dan bantuan ketika mengalami kesulitan dalam proses belajar, dan akan lebih selektif dalam memilih strategi pengaturan diri yang sesuai untuk mencapai prestasi akademik. Motivasi yang tinggi akan menyebabkan strategi pengaturan diri dalam belajar yang tinggi pula sehingga akan berdampak pada peningkatan pencapaian prestasi akademik remaja. Ryan dan Deci (2000) mengatakan bahwa seseorang yang memiliki motivasi akan menghasilkan kualitas belajar dan kreativitas yang tinggi sehingga dapat meningkatkan prestasi akademiknya.

Strategi pengaturan diri dalam belajar tidak semata-mata dilihat sebagai proses di dalam diri (kemampuan dan pengetahuan siswa), tetapi juga sebagai proses yang dipengaruhi secara timbal balik oleh lingkungan dan perilaku. Konteks sosial dan interaksi sosial memiliki peranan penting di dalam pengembangan strategi pengaturan diri dalam belajar sehingga strategi pengaturan diri dalam belajar berkembang karena adanya interaksi antara individu dengan konteks sosial (Novita \& Latifah, 2014). Penelitian ini menemukan bahwa sebagian besar remaja menggunakan strategi pengaturan diri dalam belajarnya dengan strategi effort regulation dan hampir seluruh remaja memiliki prestasi akademik yang masuk ke dalam kategori baik. Hasil penelitian ini juga sejalan dengan Novita dan Latifah (2014) yang menemukan bahwa effort regulation yang diterapkan anak di dalam belajar memiliki pengaruh yang signifikan terhadap peningkatan prestasi akademik. Motivasi seseorang dapat diduga dari banyaknya usaha yang telah diperlihatkannya. Usaha ini akan meningkatkan motivasi individu yang pada akhirnya akan membuat seseorang pantang menyerah dalam menghadapi tugas yang sulit (salah satu bentuk effort regulation). Pintrich et al. (1991) menuliskan bahwa manajemen usaha memiliki peranan penting bagi kesuksesan secara akademik karena tidak hanya menunjukkan komitmen terhadap tujuan tetapi juga mengatur penggunaan terusmenerus strategi di dalam belajar.

Prestasi akademik adalah suatu hubungan kompleks antara kemampuan individu, persepsi diri, penilaian terhadap tugas, harapan akan kesuksesan, strategi kognitif dan regulasi diri, gender, gaya pengasuhan, status sosio-ekonomi, kinerja, dan sikap individu terhadap sekolah (Sui-Chu, 2005). Metallidou dan Vlachou (2010) menyatakan bahwa tingkat prestasi seseorang berjalan seiring dengan prosedural (bijaksana dalam memilih strategi yang digunakan) dan kondisional pengetahuan tentang strategi 
pengaturan diri dalam belajar yang tersedia (mengetahui tentang bagaimana, kapan, dan dimana harus menggunakan strategi tersebut). Remaja yang memiliki strategi pengaturan diri yang baik cenderung memiliki catatan prestasi akademik yang baik pula (Sui-Chu Ho, 2005; Zimmerman \& Pons, 1986); semakin tinggi strategi pengaturan diri dalam belajar maka semakin tinggi pula prestasi akademiknya (Salmeron-Perez et al., 2010).

Hasil penelitian menunjukkan bahwa lama pendidikan ibu memiliki pengaruh negatif signifikan terhadap prestasi akademik remaja. Hal ini diduga bahwa ibu dengan pendidikan rendah tidak bekerja sehingga memiliki waktu yang lebih banyak untuk menemani anak dan mengoptimalkan prestasi akademik anak. Hasil ini sejalan dengan Abuya et al. (2014) yang menyatakan bahwa lama pendidikan ibu berpengaruh negatif terhadap prestasi belajar, namun bertolak belakang dengan Kaplan et al. (2001) dan Suksmadi et al. (2009) yang menemukan lama pendidikan ibu berpengaruh positif signifikan terhadap prestasi akademik remaja. Hasil penelitian ini juga sesuai dengan penelitian Situmorang dan Latifah (2014) yang menyatakan bahwa anak dari orang tua yang lama pendidikannya rendah memiliki prestasi akademik yang lebih baik dibandingan dengan anak yang lama pendidikan orang tuanya tinggi. Anak dalam keluarga diharapkan dapat bertanggung jawab pada kondisi keluarganya sehingga dituntut untuk memiliki prestasi yang lebih baik dibandingkan kedua orang tuanya. Sebaliknya, orang tua yang berpendidikan tinggi akan mendukung perkembangan anak dengan melihat kegiatan belajar sebagai sebuah proses tanpa melihat hasil akhirnya saja.

Pengaruh negatif signifikan juga ditemukan pada gaya pengasuhan otoriter terhadap prestasi akademik remaja. Hal ini diduga karena gaya pengasuhan otoriter memberikan kontrol yang sangat ketat, kurang memberi kehangatan, tidak memberikan alasan atas harapan dan larangan, serta tidak mengizinkan anak untuk mengekspresikan pandangannya, dan sering mempertahankan posisinya dengan menggunakan tekanan. Hasil ini sejalan dengan Huey et al. (2013) yang menyatakan bahwa gaya pengasuhan otoriter berpengaruh negatif signifikan terhadap prestasi akademik. Anak yang diasuh dengan gaya pengasuhan otoriter cenderung sering berbuat kekacauan, mencari perhatian, sedikit menggunakan waktunya untuk mengerjakan tugas, dan suka melakukan tindakan yang bertentangan di sekolah (Schickedanz, 1995).Penelitian
Alfiasari. Latifah, dan Wulandari (2011) menunjukkan semakin tinggi skor persepsi gaya pengasuhan otoriter yang dirasakan remaja maka semakin rendah prestasi akademik.

Sementara itu, penelitian ini menemukan bahwa gaya pengasuhan otoritatif berpengaruh positif signifikan terhadap prestasi akademik remaja. Hasil ini sejalan dengan penelitian Seth dan Ghormode (2013) yang menyatakan bahwa terdapat pengaruh positif signifikan yang kuat antara gaya pengasuhan otoritatif dengan prestasi akademik. Gaya pengasuhan otoritatif menjadi gaya pengasuhan terbaik untuk diterapkan secara konsisten pada anak agar menghasilkan outcome anak yang optimal (Calhoun \& Acocella, 1990; Gracia \& Gracia, 2009). Pengasuhan yang diterapkan orang tua memengaruhi kemampuan anak dalam memotivasi diri, khususnya di bidang akademik.

Temuan lain dalam penelitian ini juga menemukan adanya pengaruh positif signifikan strategi pengaturan diri dalam belajar terhadap prestasi akademik remaja. Strategi pengaturan diri merupakan salah satu prediktor terbaik antara motivasi dan prestasi akademik (Pintrich \& De Groot, 1990; Metallidou \& Vlachou, 2010). Hal ini menunjukkan bahwa penggunaan strategi pengaturan diri sangat berpengaruh terhadap peningkatan prestasi akademik remaja. Hasil penelitian Novita dan Latifah (2014); Situmorang dan Latifah (2014) juga menyatakan bahwa strategi pengaturan diri dalam belajar memiliki pengaruh langsung positif terhadap prestasi akademik. Penelitian ini menegaskan bahwa baik faktor diri khususnya strategi pengaturan diri dalam belajar dan juga faktor keluarga dalam bentuk gaya pengasuhan yang seimbang antara kontrol diri dan kasih sayang berperan lebih nyata terhadap prestasi akademik remaja.

\section{SIMPULAN DAN SARAN}

hasil penelitian menemukan bahwa ebih dari separuh remaja memiliki ayah dan ibu berusia dewasa madya dengan lama pendidikan di bawah 12 tahun. Besar keluarga remaja dalam penelitian ini terkategori sedang (5-7 orang) dengan 75,8 persen keluarga remaja memiliki pendapatan per kapita di atas garis kemiskinan. Partisipan remaja dalam penelitian ini sebagian besarnya adalah remaja perempuan dan sebagian besar remaja memersepsikan gaya pengasuhan yang 
diterapkan orang tuanya adalah otoritatif. Hasil lain juga menemukan bahwa lebih dari separuh remaja memiliki motivasi kategori sedang dan strategi pengaturan diri dalam belajar kategori rendah. Model regresi menemukan bahwa ibu-ibu yang berpendidikan SMA atau dibawahnya dan memperoleh gaya pengasuhan otoriter dari orang tuanya secara nyata lebih berpeluang mempunyai prestasi akademik yang lebih rendah. Sementara itu, remaja yang memperoleh gaya pengasuhan otoritatif dari orang tua dan mempunyai strategi pengaturan diri yang lebih beragam dalam belajar mempunyai peluang lebih besar dan lebih nyata untuk mempunyai prestasi belajar yang lebih baik.

Gaya pengasuhan otoritatif adalah salah satu gaya pengasuhan yang paling baik untuk diterapkan karena memiliki pengaruh yang cukup besar dalam pencapaian prestasi akademik remaja. Oleh sebab itu, orang tua dapat membantu remaja dalam meningkatkan prestasi akademiknya dengan mempertahankan gaya pengasuhan otoritatif dan mulai menghilangkan gaya pengasuhan otoriteryang ditemukan secara nyata berpengaruh menurunkan prestasi akademik remaja. Orang tua dapat memberikan perhatian, pujian, dan kehangatan dengan meningkatkan intensitas komunikasi dengan remaja, serta mengurangi tuntutan kepada, dan mempererat hubungan agar dapat menjadi tempat curahan atas segala permasalahan yang sedang dihadapinya. Selain itu, orang tua dapat membantu dan membimbing dalam mengerjakan tugas sekolahnya, serta mengawasi aktivitas remaja setelah pulang sekolah. Penelitian lebih lanjut mengenai prestasi akademik dapat dikembangkan dengan menambahkan variabel-variabel lain yang diduga memiliki pengaruh terhadap prestasi akademik namun belum diteliti dalam penelitian ini, seperti selfesteem, self efficacy, atau variabel lainnya.

\section{DAFTAR PUSTAKA}

[BKKBN]. Badan Koordinasi Keluarga Berencana Nasional. (1998). Data Besar Keluarga. Jakarta: BKKBN.

[BPS]. Badan Pusat Statistik. (2011). Provinsi Jawa Barat [internet]. [diunduh pada 2014 Mei 15]. Tersedia pada: www.jabar.bps.go.id/subyek/jumlahdanpresentase- penduduk-miskin-dan- garis-kemiskinan-menurutkabupatenkota-2011.

[IEA]. International Association for the Evaluation of Educational Achievement. (2011). Highlight from TIMSS 2011: The South African Perspective. Human Sciences Research Council (HSRC): IEA.

[OECD]. Organization for Economic Cooperation and Development. (2015). PISA 20 Database. Program for Internasional Student Assesment (PISA) Result from PISA 2015. www.oecd.org.edu/pisa

[Permendikbud]. Peraturan Pemerintah Pendidikan dan Budaya No. 81A Tahun 2013 tentang Implementasi Kurikulum [internet]. [diunduh pada 2014 Mei 27]. Tersedia pada: urip.files.wordPr.com/2013 /06/salinanpermendikbud-nomor-81a-tahun-2013tentang-implementasi-kurikulumgaruda.pdf

Abuya, B.A., Mutisya, M., Ngware, M. (2014). Assosiation between mother's education and grade six children numeracy and literacy in Kenya.Education. 41(6), 3-13, DOI:

https://doi.org/10.1080/03004279.2013.8 $\underline{55250}$

Alfiasari., Latifah, M., \& Wulandari, A. (2011). Pengasuhan otoriter berpotensi menurunkan kecerdasan sosial, selfesteem, dan prestasi akademik remaja. Jurnal IImu Keluarga dan Konsumen,4(1),46-56, DOI: http://dx.doi.org/10.24156/jikk.2011.4.1. 46

Baumrind, D. (1972). An exploratory study of socialization effects on Black children: Some Black-White comparisons. Child Development, 43, 261-267.

Baumrind, D. (1991). The influence of parenting style on adolescent competence and substance use. Journal of Early Adolescence. 11(1). 56-95.

Brooks, J.B. (2001). Parenting, Third Edition. California: Mayfield Publishing Company

Calhoun, J.F., Acocella, J.S. (1990). Psikologi tentang Penyesuaian dan Hubungan Kemanusiaan. Jakarta: Erlangga.

Clark, F. (1983). Self administered desensitization behavior and therapy. Journal of Behavior. 11: 56-59. 
Cramer, K.E. (2002). The influences of parenting styles on children's classroom motivation (Tesis). The School of Human Ecology, Louisiana State University and Agricultural and Mechanical College.

Dariyo, A. (2013). Dasar-dasar Pedagogi Modern. Jakarta (ID): Indeks.

Dwairy, M., Achoul, M., Abouserie, R., Farah, A., Sakhleh, A.A., Fayad, M., Khan, H.K. (2006). Parenting styles in Arab societies: A first cross-regional research study. Journal of Cross-Cultural Psychology. 37: 230-247.

Elmanora., Muflikhati, I., \& Alfiasari. (2012). Gaya pengasuhan dan perkembangan sosial emosi anak usia sekolah pada keluarga petani kayu manis. Jurnal IImu Keluarga dan Konsumen,5(2),128-137, DOI:

http://dx.doi.org/10.24156/jikk.2012.5.2. 128

Gracia, F., Gracia, E. (2009). Is always otoritatif the optimum parenting style? Evidence from spanish families. Adolescence. 44 (173),101-131

Gunarsa. (2010). Dasar dan Teori Perkembangan Anak. Jakarta: BPK. Gunung Mulia.

Hastuti, D. (2006). Analisis pengaruh model pendidikan prasekolah pada pembentukan anak sehat, cerdas, dan berkarakter secara berkelanjutan (Disertasi). Institut Pertanian Bogor, Bogor, Indonesia.

Hidayat, Y., Budiman, D. (2000). Pengaruh penerapan pendekatan model selfregulated learning terhadap motivasi belajar siswa dalam pembelajaran penjas di Sekolah Dasar (Tesis). Universitas Gajah Mada,Yogyakarta, Indonesia

Huey, E.L., Sayler, M.F., Rinn, A.N. (2013). Effects of family functioning and parenting style on early entrant's academic performance and program completion. Journal for the Education of the Gifted. 36 (4): 418-432.

Hurlock, E.B. (1980). Psikologi Perkembangan Edisi ke 5. Istiwidayanti, Soedjarwo, penerjemah. Jakarta: Erlangga. Terjemahan dari: Development Psychology, A life Span Approach, Fifth Edition (Psikologi Perkembangan, Suatu Pendekatan Sepanjang Rentang Kehidupan).
Inayah, E.R.N. (2013). Motivasi berprestasi dan self-regulated learning. Jurnal Online Psikologi. 1(2).

Indrawati, A., \& Alfiasari. (2016). Dukungan informasional orang tua: penentu keberhasilan prestasi akademik anak di perdesaan. Jurnal IImu Keluarga dan Konsumen,9(3),159-170, DOI: http://dx.doi.org/10.24156/jikk.2016.9.3. 159

Kaplan, D.S., Liu, X., Kaplan, H.B. (2001). Influence of parent's self-feelings and expectations on children's academic performance. The Journal of Education Research. 96 (6), 360-370

Kelly, D., Xie, H., Nord, C.W., Jenkins, F., Chan, J.Y., Kastberg, D. (2013). Performance of U.S. 15-Year-Old Students in Mathematics, Science, and Reading Literacy in an International Context: First Look at PISA 2012 (NCES 2014- 024). Washington DC: U.S. Department of Education, National Center for Education Statistic.

Megawangi, R., Latifah, M., Dina, W.F. (2008). Pendidikan Holistik. Jakarta: Indonesia Heritage Foundation.

Metallidou, P., Vlachou, A. (2010). Children's self regulated learning profile in language and mathematics: The role of task value beliefs. Psychology in the Schools. $\quad 47 \quad$ (8), 776788,DOI:doi/pdf/10.1002/pits.20503

Novita, L., Latifah, M. (2014). Strategi pengaturan diri dalam belajar sebagai mediator harapan orang tua dan motivasi intrinsik terhadap prestasi akademik. Jurnal IImu Keluarga dan Konsumen, 7 (3): 143-153, DOI: http://dx.doi.org/10.24156/jikk.2014.7.3. 143

Papalia, D.E., Olds, S.W., Feldman, R.D. (2008). Human Development Tenth Edition. New York: The McGraw Hill Companies, Inc.

Pintrich, P.R., De Groot, E.V. (1990). Motivational and self-regulated learning components of classroom academic performance. Journal of Educational Psychology. 82(1): 33-40.

Pintrich, P.R., Smith, D.A.F., Garcia, T., \& McKeachie, W.J. (1991). A manual for the use of the Motivated Strategies for Learning Questionnaire (MSLQ). Ann Arbor: University of Michigan, National 
Center for Research to Improve Postsecondary Teaching and Learning.

Purdie, N., Carrol, A., Roche, L. (2004). Parenting and adolescent self regulation. Journal of Adolescence. 27 (6): 663-676.

Ryan, R.M., Deci, E.L. (2000). Intrinsic and extrinsic motivations: Classic definitions and new directions. Contemporary Educational Psychology. 25: 54-67.

Salmeron-Perez, H., Gutierrez-Braojos, C., Fernande-Cano, A., Salmeron-Vilche, P. (2010). Self-regulated learning, selfefficacy beliefs and performance during the late childhood. Relieve. 16(2):1-18.

Santrock, J.W. (2003). Perkembangan Remaja. Shinto, Adelar, Saragih S, penerjemah. Jakarta: Erlangga. Terjemahan dari: Adolescence.

Seth, M., Ghormode, K. (2013). The impact of otoritatif parenting style on educational performance of learners at high school level. International Research Journal of Social Sciences. 2 (10), 41-54

Skinner, E., Sandy, J., \& Tatiana, S. (2005). Six dimensions of parenting: a motivational model. Parenting: Science and Practice, 5(2), 175-235.

Soemanto, W. (2006). Psikologi Pendidikan. Jakarta: Rineka Cipta.

Srinovita, Y., Hastuti, D., Muflikhati, I. (2012). Pola asuh akademik, ketersediaan stimulasi, dan prestasi akademik pada remaja dengan perbedaan latar belakang pendidikan prasekolah. Jurnal IImu Keluarga dan Konsumen. 5(2): 147-156.
Sui-Chu, Ho E. (2005). Self regulated learning and academic achievement of Hongkong Secondary School Students. Education Journal. 32 (2),87-107

Suksmadi, I., Sumarwan, U., Khomsan, A., Hartoyo. (2009). Kualitas remaja di Kabupaten Banyumas. Jurnal IImu Keluarga dan Konsumen,2(2),154163,DOI: http://dx.doi.org/10.24156/jikk.2009.2.2. 154

Tavani, C.M., Losh, S.C. (2003). Motivation, self-confidence, and expectations as predictors of the academik performances among our high school students. Child Study Journal. 33 (3): 141-151.

Turner, E.A., Chandler, M., Heffer, R.W. (2009). The influence of parenting styles, achievement motivation, and self efficiacy, on academic performance in college students. Journal of College Student Development. 50 (3): 337-346.

Zahra, Y., \& Hernawati, N. (2015). Prokrastinasi akademik menghambat peningkatan prestasi akademik remaja di wilayah perdesaan. Jurnal IImu Keluarga dan Konsumen,8(3),163-172, DOI: http://dx.doi.org/10.24156/jikk.2015.8.3. 163

Zimmerman, B.J., Martinez-Pons, M. (1986). Development of a structured interview for assessing student use of selfregulated learning strategies. America Educational Research Journal. 23(4): 614-628. 